\title{
Introducing Volume 14 of Regenerative Medicine
}

\author{
Adam Price-Evans*,1 \\ ${ }^{1}$ Future Science Group, Unitec House, 2 Albert Place, London N3 1QB, UK \\ *Author for correspondence: a.price-evans@futuremedicine.com
}

First draft submitted: 19 December 2018; Accepted for publication: 19 December 2018; Published online: 20 December 2018

Keywords: Award for Cultivating Excellence $\bullet$ cell therapy $\bullet$ degeneration $\bullet$ glossary $\bullet$ iPSC $\bullet$ regeneration $\bullet$ regenerative Medicine • RegMedNet • stem cell • transplantation

\section{Introduction}

To all of our readers, I would like to begin 2019 by wishing you a Happy New Year and by introducing you all to the 14th Volume of Regenerative Medicine. In this foreword I will present some selected highlights from 2018 in addition to looking forward to the year ahead.

\section{Content highlights in 2018}

Towards the end of 2017, we published a two-part Special Focus Issue entitled 'Regenerative Medicine in Society: Interdisciplinary Perspectives' $[1,2]$. This expansive collection offers perspectives on key social, ethical, policy and regulatory issues across many areas of the rapidly evolving field of regenerative medicine. On this project, the journal partnered with the European Commission-funded EuroStemCell project, which aims to educate the public on stem cells and their impact on society.

We have continued to showcase the latest and best research in clinical translation, commercialization and regulation in this rapidly evolving sector and provided a specialist forum addressing the important challenges facing the field. In Volume 13, we published a large number of high-impact and insightful articles across a wide range of topics within the ever-evolving field of regenerative medicine. Table 1 details the ten most-read articles published in Regenerative Medicine in 2018 [3-12].

At the time of writing, the most read article of 2018 in Regenerative Medicine is a Commentary entitled 'Lessons for reviewing clinical trials using induced pluripotent stem cells: examining the case of a first-in-human trial for agerelated macular degeneration' [3]. In this piece, the authors examined the minutes of the ethical review committee meetings for the first-in-human trial using iPSCs with the aim of identifying lessons for similar committees in the future.

The second most accessed article of 2018 was a White Paper entitled 'Quality control guidelines for clinical-grade human induced pluripotent stem cell lines.' This article summarized the key conclusions from two workshops and offered an international consensus focused on critical quality attributes and minimum testing requirements for clinical-grade iPSC lines [4].

Another highly read article in Volume 13 was 'Cell therapy-processing economics: small-scale microfactories as a stepping stone toward large-scale macrofactories' [6]. In this Research Article, the authors presented a case study examining small-scale manufacturing methods for cell-based therapies. They employed cell expansion research data, combined with operational cost modelling, to study the feasibility of cell microfactories for novel mesenchymal stem cell-based therapies.

Our top-scoring paper on the Altmetric platform [13] in 2018 was the Research Article entitled, 'Retrorectus repair of incisional ventral hernia with urinary bladder matrix reinforcement in a long-term porcine model' [14]. This article presents the evaluation of the remodeling characteristics of the abdominal wall in a porcine model of ventral hernia repair following reinforcement with urinary bladder matrix-derived surgical devices. This work received attention from numerous news outlets from around the world, which contributed to its high Altmetric score. 


\begin{tabular}{|c|c|c|}
\hline Rank & Title & Refs. \\
\hline 1 & $\begin{array}{l}\text { Lessons for reviewing clinical trials using induced pluripotent stem cells: examining the case of a first-in-human trial for age-related } \\
\text { macular degeneration }\end{array}$ & [3] \\
\hline 2 & Quality control guidelines for clinical-grade human induced pluripotent stem cell lines & [4] \\
\hline 3 & Direct-to-consumer marketing of stem cell interventions by Canadian businesses & [5] \\
\hline 4 & Cell therapy-processing economics: small-scale microfactories as a stepping stone toward large-scale macrofactories & [6] \\
\hline 5 & Fibroblasts and wound healing: an update & [7] \\
\hline 6 & Cytokines in umbilical cord blood-derived cellular product: a mechanistic insight into bone repair & [8] \\
\hline 7 & Biochemical characterization of pure dehydrated binate amniotic membrane: role of cytokines in the spotlight & [9] \\
\hline 8 & Conference Report: 6th Annual International Symposium on Regenerative Rehabilitation & [10] \\
\hline 9 & Pure platelet-rich plasma and supernatant of calcium-activated P-PRP induce different phenotypes of human macrophages & [11] \\
\hline 10 & Selling stem cell 'treatments' as research: prospective customer perspectives from crowdfunding campaigns & [12] \\
\hline
\end{tabular}

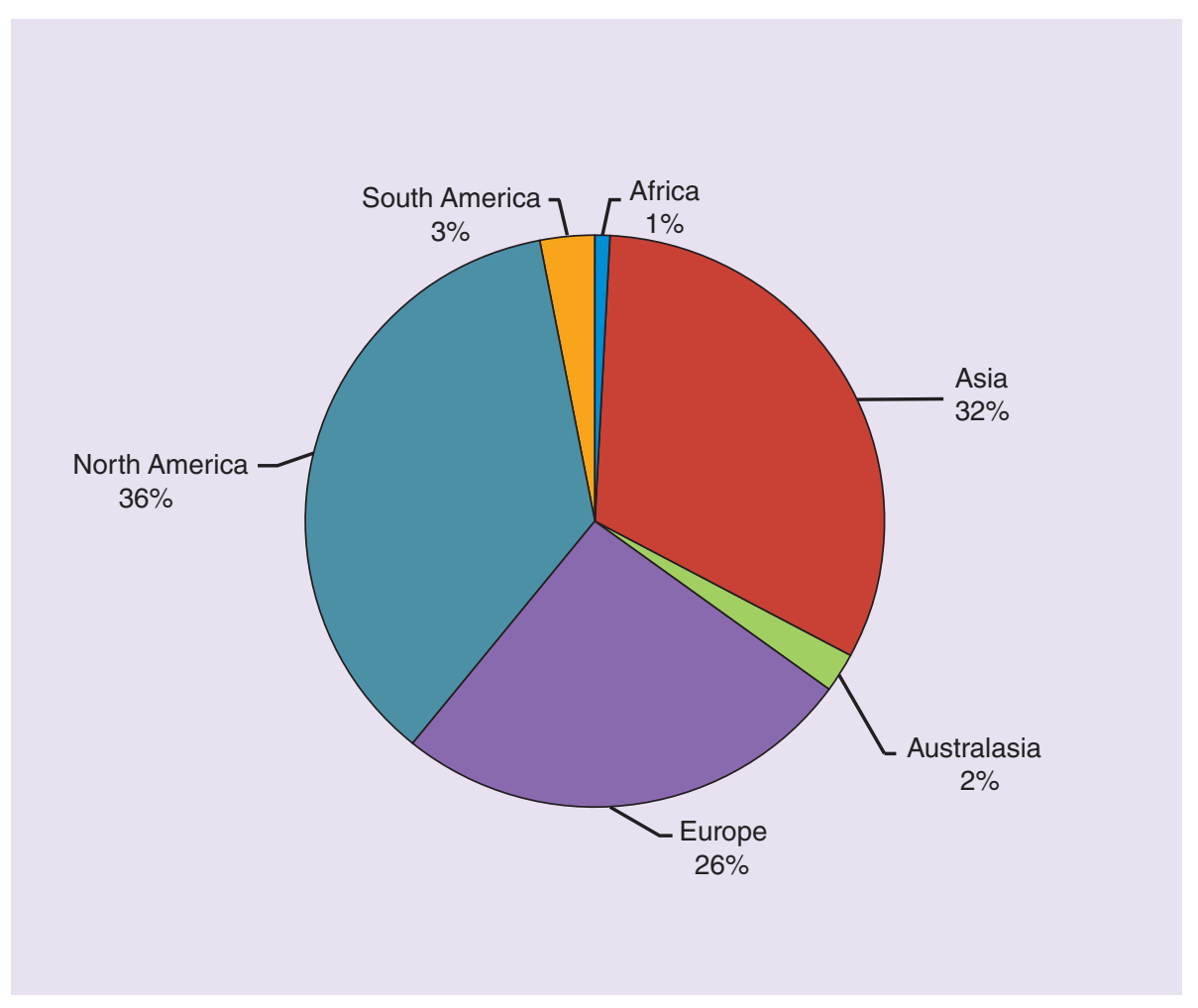

Figure 1. Approximate proportion of readership demographics for Regenerative Medicine in 2018 by continent.

\section{Readership demographics}

As the regenerative medicine research community continues to grow, the readership of Regenerative Medicine changes. In 2018 , our content was most read by experts in the USA $(\sim 30 \%)$, the UK \& Ireland $(\sim 10 \%)$ and China $(\sim 10 \%)$. Figure 1 depicts the approximate proportions of the Regenerative Medicine readership by continent. In 2018, we have seen a significant rise in the proportion of our readership coming out of Asia compared with last year, which is indicative of the field's growth in this area [15].

While our content continues to have impact across Europe and North America, we expect to see a continued growth in emerging scientific communities and look forward to continuing the circulation of our content to an increasingly global audience. 


\section{The Glossary for Cell \& Gene Therapy and Regenerative Medicine: Fourth Edition}

In 2018, our in-house editorial team worked closely with leading experts from industry and academia in regenerative medicine and related fields to provide the fourth edition of the Regenerative Medicine glossary. Not only were all previous definitions updated but almost 100 new terms were added. Based on continued advances and growth in the field of gene therapy, we expanded the glossary's scope and defined a large number of terms associated with this area of research. This expanded coverage is reflected in the glossary's new title: The Glossary for Cell \& Gene Therapy and Regenerative Medicine [16].

This glossary is directed toward both experts and newcomers within academic, clinical, industry and societal settings and aims to aid harmonization of the terminology used across the world. With this exciting area of research continuingly becoming more present in the public eye, it is also highly important that effort is made to help educate and enhance global understanding. The glossary therefore aims to bridge the gap between scientists working in the field and the general public as well as to benefit anyone interested in learning more about this field.

\section{Social media}

Regenerative Medicine's social media presence has continued to grow throughout 2018. We were delighted to reach over 2700 followers on the journal's Twitter account (@Regen_Med) [17] and this number has continued to rise. The journal also has a LinkedIn group, open to all [18]. We regularly post journal highlights across these platforms, including newly published content and issues, offers and the latest news in the field.

\section{RegMedNet}

As many readers will be aware, Regenerative Medicine is proud to be partnered with and work alongside RegMedNet [19], a free-to-access networking site with over 13,000 members (at the time of writing). The site aims to promote global collaboration between all members of the diverse regenerative medicine field. RegMedNet aims to provide up-to-date, essential research and information on all aspects of regenerative medicine, from the bench to the bedside. RegMedNet offers easy access to breaking news, exclusive features, interviews, video content, webinars and peer-reviewed journal articles from Regenerative Medicine.

The journal's partnership with RegMedNet provides us the unique opportunity to further showcase and disseminate work published in Regenerative Medicine across multiple platforms and to a wider audience, adding great benefit to our authors and driving their influence in the field. For example, the research article from Sane et al. [9], which demonstrates how cytokines and growth factors within a uniquely folded dehydrated binate amniotic membrane positively affected the biological efficacy of the membrane in wound healing, was featured on RegMedNet this year [20] and was ultimately one of the journal's most read papers, recording our second highest Altmetric score in 2018.

We are always looking to find new ways to shine a spotlight on and expand access to research published in the journal through RegMedNet. With this in mind, RegMedNet has also introduced the 'Peek behind the paper' feature which allows our audience to gain additional information and insight into the ground-breaking research published in Regenerative Medicine, whilst simultaneously providing our authors with the opportunity to offer additional thoughts and perspectives on their work and the surrounding field.

A prime example of this is an exclusive interview with Leigh Turner (University of Minnesota, MN, USA) [21], in which he discusses his original research article that examines marketing claims made by Canadian companies and clinics engaged in direct-to-consumer online marketing of purported stem cell treatments [5]. This article received our third highest Altmetric score and was one of the journal's most read papers of 2018 (see Table 1). This interview gave Turner the opportunity to discuss the reasoning and importance of this work, to offer opinions on the potential impact of this research and the lessons that should be learned going forward, in addition to delving a little deeper in to some of the surrounding issues.

In 2018, RegMedNet, in partnership with Regenerative Medicine, filmed and published its first panel discussion in which five industry experts openly discussed key topics surrounding the 'Business of regenerative medicine' [22]. This expert panel included Michael May (Centre for Commercialization of Regenerative Medicine, ON, Canada), Robert Preti (Hitachi Chemical Advanced Therapeutics Solutions, NJ, USA), Robert Jones (Fisher Bioservices, MA, USA), Carolyn Yeago (Georgia Institute of Technology, GA, USA) and Qasim Rafiq (University College London, UK). Topics discussed included preservation and the challenges of delivering a high quality product, regulation and the issue of comparability, and what the manufacturing facility of the future might look like. This filmed panel discussion offers easily accessible and important insight for those working or even just interested in the 
field, whilst further benefiting those unable to attend events in person. We look forward to bringing our audience additional panel discussions in 2019.

\section{The RegMedNet Award for Cultivating Excellence}

In 2017, RegMedNet, in partnership with Regenerative Medicine, established the Award for Cultivating Excellence [23]. In the belief that that the most valuable players in regenerative medicine aren't always those seen in the news, the aim of the Award for Cultivating Excellence is to recognize achievement in the field by celebrating any labs/groups that promote career development, undergraduate training, collaboration, innovative research and public outreach.

From almost 50 labs nominated around the world, the 2018 RegMedNet Award for Cultivating Excellence was awarded to BellaSeno GmbH (Leipzig, Germany) [24], a preclinical stage medical device company developing innovative porous bioresorbable breast implants. We would like to congratulate all members of the BellaSeno $\mathrm{GmbH}$ lab. Their nominator cited their belief that "in order for additive manufacturing to reach its true potential in the field of medicine, training of young engineers and biologists is of paramount importance. . [and] the students are awarded authorship in all publications and patents that directly result from their work at BellaSeno" as some of the reasons for the nomination.

BellaSeno $\mathrm{GmbH}$ won the public vote after five finalists were shortlisted by an expert judging panel; the other finalists included the StaalLab (Leiden University Medical Center, the Netherlands), the Biotechnology Unit at the University of Suffolk (UK), Roger Barker's lab (University of Cambridge, UK) and the Yin Laboratory at the MxDI Biological Laboratory (ME, USA). This year also saw the introduction of a public vote, with almost 1000 votes cast for the five finalists.

To highlight the achievements of BellaSeno GmbH, the team were the subject of a month-long special feature on RegMedNet, featuring interviews with lab members and selected published research. They also received a year-long subscription to a Future Science Group title of their choice, and 50\% off open access fees for up to five articles published in Regenerative Medicine.

\section{Conference attendance}

As we do every year, members of the Regenerative Medicine team attended a number of conferences, meetings and events around the world throughout 2018, in order to meet our readers, authors, Editorial Board members and collaborators, as well as keep up-to-date with the field and ensure that we are covering all the latest and ground-breaking research. Some of the key events we attended include the World Stem Cell Summit in Miami (22-26 Jan 2018, FL, USA), the annual International Society for Cellular Therapy (ISCT) meeting in Montreal (2-5 May 2018, QC, Canada) and the Regenerative Medicine Japan expo in Yokohama (9-11 Oct 2018, Japan).

In order to keep up-to-date with events the Regenerative Medicine team will be attending in 2019, follow us on Twitter [17], join our LinkedIn group [18] or become a member of RegMedNet [19].

\section{Conclusion}

We appreciate all feedback from the regenerative medicine community regarding the direction of our content, especially suggestions of any priority topics in the field that you feel the journal should cover. We welcome unsolicited research, review and opinion article proposals, amongst others, and would be delighted to hear from you if you are interested in submitting to the journal.

I would also like to take this opportunity to thank our readers, contributing authors, valued Editorial Board members and peer reviewers for their continued support and collaboration as we continue to publish the latest research, reviews and opinions. We very much look forward to working with you all over the next year and hope to see Regenerative Medicine continue to grow and serve the research community in 2019.

Financial \& competing interests disclosure

Adam Price-Evans is an employee of Future Medicine Ltd, publisher of Regenerative Medicine. The author has no other relevant affiliations or financial involvement with any organization or entity with a financial interest in or financial conflict with the subject matter or materials discussed in the manuscript apart from those disclosed.

No writing assistance was utilized in the production of this manuscript. 


\section{References}

1 Rosemann A, Barfoot J, Blackburn CC. Special focus issue on regenerative medicine in society: interdisciplinary perspectives (part I) Foreword. Regen. Med. 12(6), 577-580 (2017).

2 Barfoot J, Rosemann A, Blackburn CC. Special focus issue on regenerative medicine in society: interdisciplinary perspectives (part II) Foreword. Regen Med. 12(7), 733-736 (2017).

3 Takashima K, Inoue Y, Tashiro S, Muto K. Lessons for reviewing clinical trials using induced pluripotent stem cells: examining the case of a first-in-human trial for age-related macular degeneration. Regen. Med. 13(2), 123-128 (2018).

4 Sullivan S, Stacey GN, Akazawa C et al. Quality control guidelines for clinical-grade human induced pluripotent stem cell lines. Regen. Med. 13(7), 859-866 (2018).

5 Turner L. Direct-to-consumer marketing of stem cell interventions by Canadian businesses. Regen. Med. 13(6), 643-658 (2018).

6 Harrison RP, Medcalf N, Rafiq QA. Cell therapy-processing economics: small-scale microfactories as a stepping stone toward large-scale macrofactories. Regen. Med. 13(2), 159-173 (2018).

7 des Jardins-Park HE, Foster DS, Longaker MT. Fibroblasts and wound healing: an update. Regen. Med. 13(5), 491-495 (2018).

8 Sane MS, Misra N, Mousa OM et al. Cytokines in umbilical cord blood-derived cellular product: a mechanistic insight into bone repair. Regen. Med. 13(8), 881-898 (2018).

9 Sane MS, Misra N, Quintanar NM, Jones CD, Mustafi SB. Biochemical characterization of pure dehydrated binate amniotic membrane: role of cytokines in the spotlight. Regen. Med. 13(6), 689-703 (2018).

10 Loghmani MT, Roche JA. Conference Report: 6th Annual International Symposium on Regenerative Rehabilitation. Regen. Med. 13(4), 371-374 (2018).

11 Escobar G, Escobar A, Ascui G et al. Pure platelet-rich plasma and supernatant of calcium-activated P-PRP induce different phenotypes of human macrophages. Regen. Med. 13(4), 427-441 (2018).

12 Snyder J, Turner L. Selling stem cell 'treatments' as research: prospective customer perspectives from crowdfunding campaigns. Regen. Med. 13(4), 375-384 (2018).

13 Altmetric. (2018) www.altmetric.com/

14 Young DA, Jackson N, Ronaghan CA, Brathwaite CE, Gilbert TW. Retrorectus repair of incisional ventral hernia with urinary bladder matrix reinforcement in a long-term porcine model. Regen. Med. 13(4), 395-408 (2018).

15 Price-Evans A. Introducing Volume 13 of Regenerative Medicine. Regen. Med. 13(1), 1-5 (2018).

16 The Glossary for Cell \& Gene Therapy and Regenerative Medicine. Regen. Med. 13(8s), 1-124 (2018).

17 Twitter. (2018) https://twitter.com/Regen_Med

18 LinkedIn. (2018) www.linkedin.com/groups/4383090

19 RegMedNet. (2018) www.regmednet.com

20 Dehydrated amniotic membrane is a potential source of therapeutic cytokines for wound healing. RegMedNet (2018). www.regmednet.com/channels/713-regenerative-medicine/posts/37959-dehydrated-amniotic-membrane-is-a-potential-source-of-the rapeutic-cytokines-for-wound-healing

21 Understanding the landscape of direct-to-consumer marketing in Canada: an interview with Leigh Turner. RegMedNet (2018). www.regmednet.com/users/3641-regmednet/posts/39011-canadian-direct-to-consumer-marketing-an-interview-with-leigh-turner

22 Business of regenerative medicine: an expert panel discussion. RegMedNet (2018). www.regmednet.com/users/3641-regmednet/posts/34712-business-of-regenerative-medicine-an-expert-panel-discussion

23 Price-Evans A. Introducing the RegMedNet Award for Cultivating Excellence. Regen. Med. 13(3), 265-267 (2018).

24 RegMedNet announces latest winner of the Award for Cultivating Excellence. RegMedNet (2018). www.regmednet.com/users/3641-regmednet/posts/38865-regmednet-announces-latest-winner-of-the-award-for-cultivating-excellence 
